\title{
Concealment or spectacularisation: analysing the heritagisation process of old prisons
}

\author{
G. Swensen \\ Norwegian Institute for Cultural Heritage Research, Norway
}

\begin{abstract}
There are histories and personal narratives that will never reach the public either because they represent difficult memories or because they are of a character that society finds necessary to conceal. This paper will discuss aspects of the heritagisation process of old prison buildings taking place in Norway today. As part of major reforms in the legal system, decisions were made by the young national state in 1857 to build a network of district prisons throughout the country. They were designed in a functional, but partially symbolic form, signalising hierarchy and political power, and many of the buildings that were erected in the following years were based on drawings from some of Norway's most recognised architects. Gradually, the old prisons are now being replaced by new buildings. In the process of filling empty monumental buildings with new functions, new stories are created. The paper investigates closer the effects these changes of functions have had and asks: Are the old prisons remembered primarily as architectural monuments of power and justice, as monuments of social history that include painful personal stories, or do the arguments used by heritage management try to combine various perspectives? The study combines several qualitative methods; in field observations, informal interviews with central actors, and supplementary literature and archive studies. The discussion will be made in view of the processes of re-conceptualisation taking place as part of the position the cultural industries have gained as a new target area in urban municipal policies, as well as discussing the processes of selection in the heritagisation process.

Keywords: memory sites, dissonant heritage, prison architecture, buildings of power, urban transformation, heritage tourism, cultural industries.
\end{abstract}




\section{Introduction}

\subsection{Painful memory sites}

Memory plays a vital part when cultural heritage issues are discussed: Heritage can fill a nation's need for commemorating important past events as well as offer new personal memorable events. There is an important intersection between the individual and the collective facets of memory culture (Staiger and Steiner [1]), and old prisons can be remembered both as monuments of painful personal stories and as monuments of power and justice.

Buildings represent material structures and can be understood and read in terms of social relations. In this perspective buildings are primarily perceived as social objects - their forms provide answers to questions of power, order, classification, and function. Everything about a building has social meaning - its form, function, and spatial structure can all be objects for social analysis (Markus [2]). To erect buildings can be read as a way of signalising political or ideological power, which demonstrates the law enforcement's view of their role in society.

Some locations have been difficult to recognise as part of a national or local community's heritage because they have represented particular painful or shameful episodes. Tunbridge and Ashworth [3] have introduced the notion "dissonance" to stress a lack of agreement and consistency in heritage, which highlights a state of tension inherent in heritage (Tunbridge and Ashworth: 20 [3]). Prisons belong to a type of heritage that Logan and Reeves [4] have labelled "difficult heritage" and encompass places such as massacre and genocide sites and places related to prisoners of war. Civil and political prisons and lunatic asylums are also included (Al-Hosany and Elkadi [5], Edginton [6], Rosenthal [7], Stone and Sharpley [8], Strange and Kempa [9], Tomlinson [10]). In the interpretation of the heritage sites it is important to determine what aspects of the past are being ignored or poorly represented.

\subsection{Culture - a revitalising force in urban development}

Heritage can be used to fulfil many purposes (Smith [11]), and cultural heritage has experienced a turn from being a field of interest among experts to representing a new niche for investors. Today city and town municipalities often use culture as a way of creating an up-to-date profile in accordance with advice received from professional "branders" and image-builders (Marling and Zerlang [12], Rantisi and Leslie [13]). Heritage has been ascribed a new role in this process of revitalising city centres, adding a touch of soul and identity to a place. Cultural heritage is not primarily based in history as such, but has to do with how the contemporary society makes use of the past to fulfil present needs. This definition of cultural heritage is in accordance with the definition presented by Graham et al. [14]. Monumental buildings like prisons have potentials to be used for such revitalising purposes, and the kind of new functions redundant prisons are being filled with are discussed in this article. 


\section{A short historic sketch}

\subsection{Reformed prison system in Norway in the 19th century}

As part of the new criminal law from 1842 large prison reforms were introduced. This included the building of a series of new prisons in Norway.

Before the commission of 1839 started looking into the punishment regulations, imprisonment had taken place in military castles or in so-called "Slaveries," which represented a form of social institutions for the weakest in society. The commission suggested that the castles and slaveries should be replaced by new prisons built according to new ideas about cell imprisonment. One of the most recognised architects in the 19th century, H.E. Schirmer, studied the new prisons and hospitals in Belgium, Germany and England and used this knowledge when he was assigned several important prison projects at the time. In the new prison law from 1857 decisions were made to build 56 new regional prisons, which meant building a net of local prisons around the country. In cooperation with his partner W. von Hanno, Schirmer developed a series of model plans for regional prisons ("distrikts-og hjelpefengsler") (Schirmer and von Hanno [15], Hamran [16]), and many of the regional prisons still standing today belong to this type. While 12 out of the original 56 prisons are still in original use, the rest were either closed down and later replaced by a new prison in the same town (13) or permanently closed down (31) (Kjus [17]).

\subsection{Redundant buildings - new functions}

The number of prisons erected as a result of the introduction of prison reforms in 1857 filled the need for punishment institutions far into the 20th century.

With more recent reforms in the jurisdictional system (1958-1970), new principles of imprisonment were introduced, which led to changes in a lot of the existing prisons as well as clearing the ground for building a group of new types of prisons. However, there are still some examples of buildings still in use as prisons that to a large extent have remained unaltered, like Eidsberg prison (Nyborg [18]) and Botsfengselet in Oslo (Hamran [16], Schaanning [19]). The same is the case for the prisons in Vik, Hamar, Larvik, Gjøvik, and Ålesund, which are among the first generation of prisons from 1842 on that are now suggested protected in the new national protection plan for the legal sector (Green paper: 18-24 [20]).

Later during the 20th century the views on what constitutes the best principles for imprisonments have changed, and open institutions have become more common (Green paper: 30 [20]). With new principles of imprisonment, some of the old prisons proved outdated and were sold, and this forms the basis for the problems discussed in this paper: What happened to these buildings after they were sold? From what we know at the moment, amongst the 44 prisons that are not in original use any more, 7 were later demolished or burnt down, 9 are functioning as cultural institutions of various forms, and 4 were turned into hotels or other commercial purposes (information from local historical societies). 


\section{Whose heritage?}

A nation's conservation policy can be discussed in view of the various social meanings the assigned heritage contains and the reasons stated for including buildings on the heritage lists.

Protection of old buildings can be ensured through a series of means. While the most encompassing protection is done by use of the Norwegian Cultural Heritage Act (CHA), other buildings are managed by use of other legal options, while others again are being filled with new functions that necessitate changes of various degrees. Examples of all three forms of protection will be presented in the following chapter.

\subsection{Various ways to ensure protection}

In the group of prisons mentioned in this article two are protected through the Norwegian Cultural Heritage Act, which is the strongest protection measure at hand. The one prison that is already protected through designation (vedtaksfredet) is Hønefoss Hjelpefengsel (1862), which will be presented more closely later, and Halden prison (1864), which is undergoing protection evaluation at the moment (Wegner [21]). Other instruments such as The Plan and Building Act are also available to ensure protection at the municipal level. This form of protection is not statutorily binding in the same way, but can be seen as a form of "self-imposed protection" that each civil service is involved in (Green paper: 8-9 [20]). (Kasjotten in Skedsmo and Gamle Bergen Kretsefengsel, which are described more closely later, are both safeguarded by such means.)

Of particular importance for protection of buildings from the justice and police sector is the decision recently agreed on between the Directorate of Cultural Heritage and the Civil Services to carry out sectorial protection plans. The national plan for protection of buildings from the justice and police sector [20] is based on a survey of all the properties owned by the state and is in use today by the justice and police sector. It includes references to the police, court of justice, and the prison system ("kriminalomsorgen"). Here the focus is on the last group of buildings, the prisons.

The final aim is to "protect a representative selection of properties owned by the state to document and give insight into important aspects of the state's activities." "The selection in a national plan for protection is meant to be 'exclusive' and be limited to include the historically most important properties within each sector." It is the Norwegian Directorate for Cultural Heritage that will carry out the final approval and activate the protection process (Green paper: 5 [20]).

In the national plan an important aim has been to include prisons from various periods up until today to ensure that central changes in the legal system are portrayed. The selection is based on a set of special criteria developed via the initial work with the national protection plan supplemented with the traditional criteria in use by the Norwegian Directorate for Cultural Heritage. The main criterion is whether the property includes central aspects of the historical 
development of the sector, and shows how events, political decisions, and juridical changes are expressed in the selected properties. An outline of the history of the administration of justice and how this history relates to the sector's buildings has recently been made (Kjus [17], Fodstad [22], Stortingsmelding [23]).

In addition, considerations should be paid to geographical, chronological, and form-related variety. Consideration should also be made to the societal development among Sami and national minorities and their cultural heritage (Green paper: 8-9[20]).

During the planning process 49 prisons have been evaluated, including a total of 478 prison buildings. Twenty of them have been listed for protection in the national protection plan for the legal sector - and 12 of these properties are already protected via other regulations, either as national listed buildings or via use of the local Plan and Building Act (Green paper: 18-19 [20]). This group belongs primarily to the first generation of Norwegian prisons, which is the group of prisons discussed in this article.

\subsection{Three old prisons filled with new functions}

\subsubsection{Kasjotten (Stav Gjestegaard)}

Today it is functioning as a hotel and is situated in the outskirts of Oslo, near the main national airport. Originally named Skedsmo distriktsfengsel, it was a regional prison that opened in 1863 .

Skedsmo distriktsfengsel was built in brick after standard drawings from architects Schirmer and von Hanno and contained 35 single cells, 6 cells shared by 3-4 prisoners, an arrest cell, the courtroom, and the flat for the caretaker. Due to lack of sufficient imprisonment in the capital, a contract was signed in 1889 that stated that prisoners from the capital were sent to Skedsmo to serve their sentence. Pressure on the capacity resulted in a situation where the exercise yard became too small and had to be redesigned. After being left empty for over 20 years, the prison functioned as a home for mentally ill females between 1923 and 1975. In 1979 it was decided that the prison would be sold. Today the Plan and Building Act is used to ensure protection of the building at the municipal level.
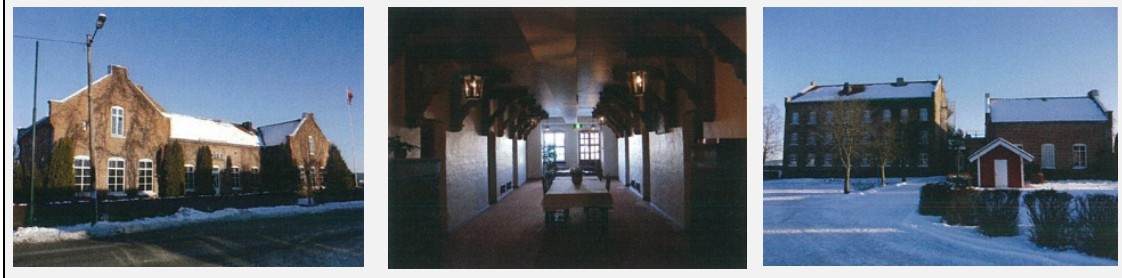

The photos show the hotel entrance, the cell corridor on the first floor, and both wings of the building from the western side. Photos: NIKU. 
Changed setting and meanings When you approach the hotel today, you reach the main entrance by passing through a small front garden where the wall is covered in ivy. There are no obvious references made to the history of the building in the way it appears to the visitors, for instance the name "Kasjotten" (an old slang for prison cell) does not figure on the nameplate on the front wall. The restoration and rebuilding of the hotel took three years when it started in 1979, and the building and its structure tells a lot of stories in itself: Each cell door with its particular hatch is intact, and massive wooden support beams stand out as decorative elements against white painted brick walls. When you walk around the building outside the iron bars, a few original cellar windows may raise your curiosity. If you happen to want to know more of the building's history, there are leaflets available that will give rather detailed information about the prison's history and the conditions the prisoners lived under, but you would have to ask for this information. A small detail - a stylised key - in the specially designed wall-to-wall carpets might draw your attention, and several rooms are renamed to bring the right associations: The banqueting hall is called "Fangehullet" (the dungeon) and the aisles "celleganger" (cell corridors).

All in all it appears to be a comfortable hotel that pays attention to period and style. Its history as a former prison is to some degree de-emphasised, but it would be wrong to argue that it is consciously under-communicated, as the naming and its play with metaphors illustrate.

\subsection{2 "Gamle Bergen kretsfengsel" (Bergen County Jail)}

Apart from visits from a couple of earlier artistic projects, Bergen County Jail has been out of use since 1991, when the new prison Bergen National Prison opened outside the city centre. It is owned today by the municipality and situated in the centre of Bergen, close to the old fire station and city hall, and is a listed building. A new alternative use is being discussed at the moment.

Changed setting and meanings The prison has been described as a "commencing ruin" [24]. The fact that the building has been abandoned more than 20 years has left obvious signs of disuse with damp walls where the wall paint is flaking. However, the main building structure is intact and there is much potential for reuse. When you enter the main hall on the ground floor, you have to pass through an iron gate, which functions as the divide between the administrative part and the cells. The offices, cells with barred windows, and solid doors with particular hatch are still in place. The fan-shaped yard can be reached via a narrow corridor and viewed from above by climbing the outside stairs (see fig.) While the alternatives for future use are being considered, the building is kept closed, and only on special occasions is the prison opened for the general public. One such happening occurred in May/June 2011. The annual musical event "Bergen International Festival" in cooperation with Bergen municipality took the initiative to engage an artist to design a happening including an overnight stay, and the artist described his assignment this way: "It is the nature of performance to be related to place, and performance artists are accustomed to relating to rooms with peculiar characteristics" (Bergen International Festival: 11 [25]). In cooperation with artists from the Bergen 
National Academy of the Arts, filmmakers, and a choir, they managed to use the happening as an acknowledgement of what a powerful media a prison is when its histories are being interpreted and translated through creative minds. This performance could only take place in a prison, and the bare and naked shell of an old prison in decay functioned as a resonator for strong personal messages that left plenty of food for thought in the audience.

"Gamle Bergen kretsfengsel" (Bergen County Jail) was completed in 1867 and was designed by the architect Franz Wilhelm Schiertz in 1861. The cell system and the fan-shaped yard on the west side of the building are modelled after the so-called Philadelphia model. The prison was originally built in three stories and had 41 cells with a longitudinal corridor and galleries. In 1920 it was extended with a new wing to accommodate female inmates and now includes 57 cells. During the Second World War the Gestapo moved in and added another story on to the west wing in 1942. At that time it held 144 inmates (Internet [24]).
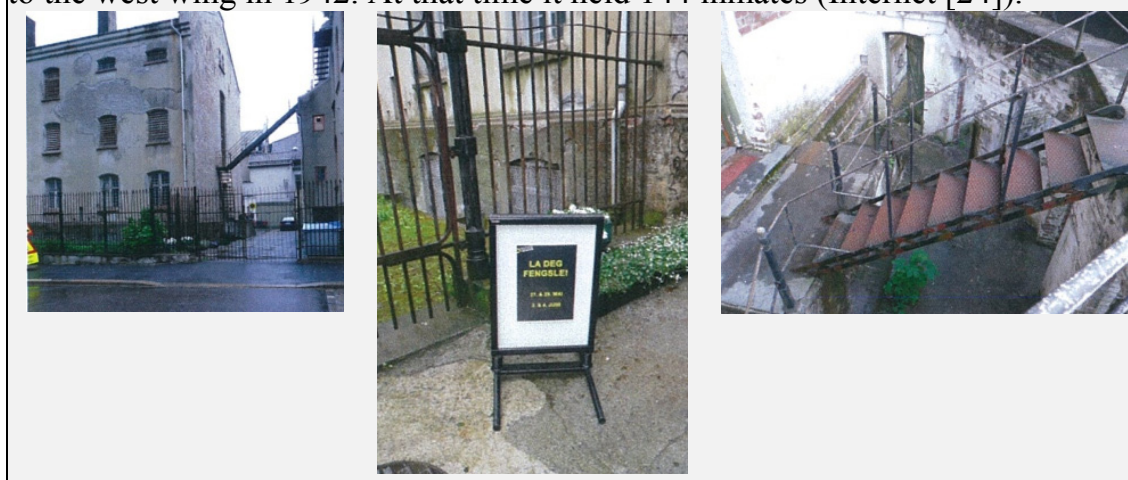

The photos show the entrance to the prison from the southern side, the notice board in front of the gate to the prison garden announcing the art event, and the upper side of the fan-shaped yard. Photos: NIKU.

Since the doors closed again in summer 2011, the discussions continue about alternative uses for the empty building. Its central location weighs strongly for the prison to be turned into some kind of cultural institution, but restoring the building to the standard required for modern use is estimated by the owners to cost between 6,5 -12,5 million euro.

\subsubsection{Stiftelsen "Fengselet"}

This former prison is situated in the centre of Hønefoss, a small town approximately $60 \mathrm{~km}$ north of Oslo. When Hønefoss celebrated its 150-year jubilee in 2002, the regional bank decided to turn the building into a gift to the people to be used as a cultural institution. 


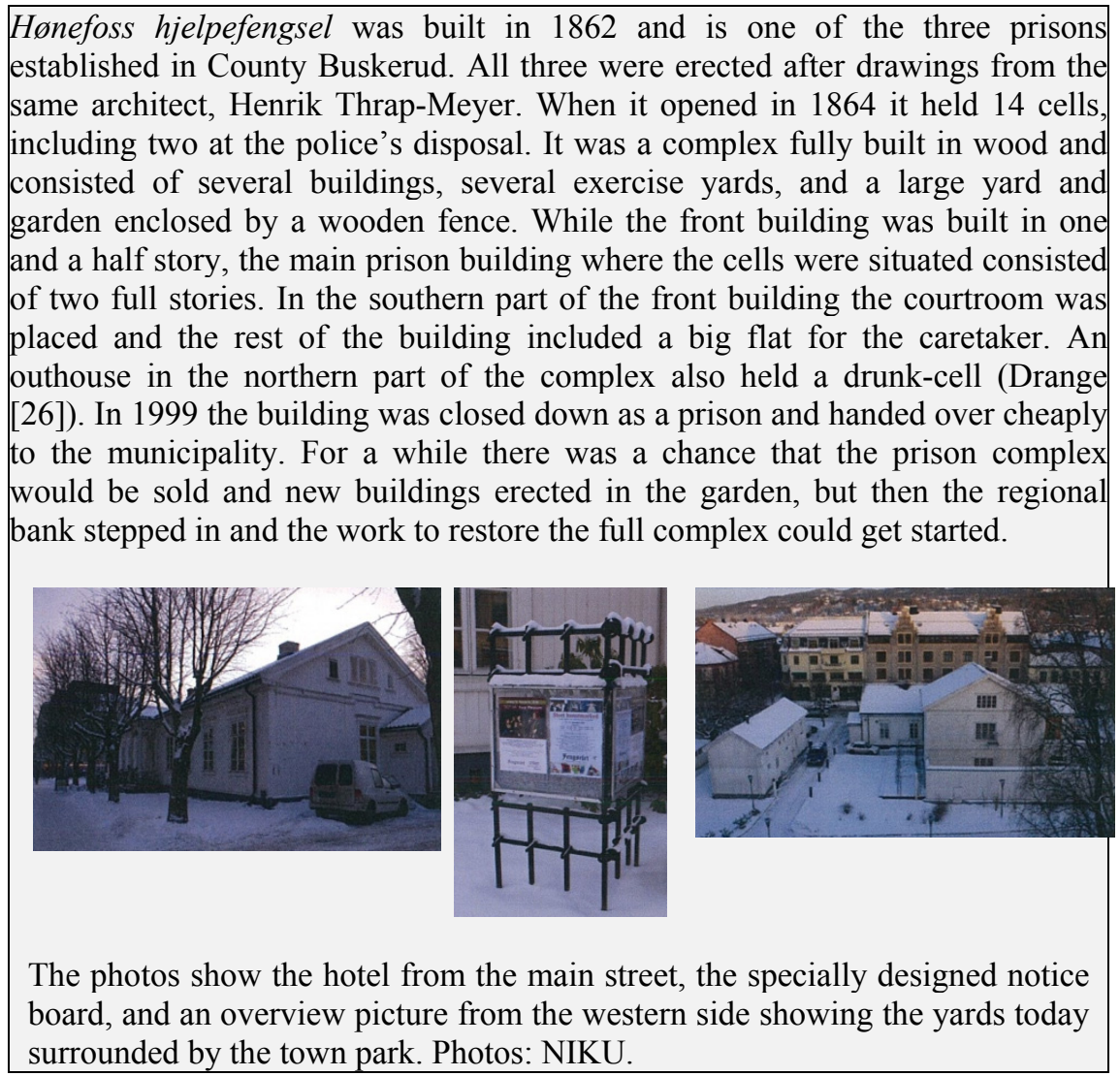

Changed setting and meanings "Fengselet" is occupying a full block of the town centre, and the area functions as an open busy town park that people pass through on their way through town. Since it changed ownership, the building complex has been assigned to preservation through CHA, and any maintenance or rehabilitation work has to be done in accordance with directions made by the Norwegian Cultural Heritage Directorate (Riksantikvaren). The building's exterior was repainted in white and grey as early as 1913, but at present restoration work is being done to recover the original nuances of yellow of the exterior. Restoration work inside has ensured that the cell corridors have kept their original stark and hostile character intact. Recently a cell has been reconstructed after the original pattern, with the bed and the desk locked to the wall in accordance with security measures laid out by the period's imprisonment idioms. An assigned culture director manages "Fengselet" today, and by combining various cultural activities, such as art exhibitions and concerts, as well as housing a restaurant, it strikes you that it represents an important institution in town. The courtroom includes a piano and is used as an intimate concert hall, and for larger concerts in the summer one of the outside exercise yards is used. Former cells function as exhibition halls and workshops for 
various artists. A specially designed notice board close to the entrance that announces the coming arrangements is constructed to give associations to the building's original function. Other arrangements play on similar associations: A yearly concert is named "the Jailhouse Rock" and is said to draw at least 400 visitors at each performance. The park called "The Prison Garden" is kept in excellent condition by the local Garden Society, and a fund named "Celledeling" (Cell sharing) has been established to encourage young musical talents in the district. Elements of the prison's history are presented in a delicate brochure available via Internet, and there is a chapter about the prison in a town history published at the town's jubilee.

The extensive restoration works are ensuring that the buildings' form and structure are presented historically correct. The troublesome personal histories the prison holds are not consciously hidden, but except for the naked, restored prison cell that through its bare minimalism tells its own story about isolation and loneliness, there are few particular references to the specific history of the building and its users except through the naming that plays on erasing curiosity. People particularly interested can of course search for the prison's history themselves, but it is not made easily available.

\section{Discussion: to sell a problematic history}

In this article old prisons are used as illustrations of the selection of histories used to portray the prisons and the prison life of the 19th century. Questions were raised as to whether the old prisons are remembered primarily as architectural monuments of power and justice, as monuments of social history including painful personal stories, or whether the arguments used by the heritage management try to combine various perspectives? The national plan for protection of buildings from the justice and police sector has a defined purpose. As already stated, "The selection ... is meant to be 'exclusive' and limited to include the historically most important properties within each sector..." "...the main criterion for the selection is stated to be "whether the property includes central aspects of the historical development of the sector, and shows how events, political decisions and juridical changes are expressed in the selected properties" (Green paper: 8-9 [20]). This argumentation resembles attitudes found in archives: to profile the architecture of the legal system with emphasis put on chronology, that is, protection of representative examples from various central periods in the legal system. The change that the legal system has undergone is a key to understanding the selection process. It would be right to claim that these reasons underline that heritage management in cooperation with the sector primarily base the selection on prisons as architectural monuments of power and justice.

When we look closer at protection in practice and the actual purposes and functions the buildings are filling, there are also other factors in action. Old buildings have to be filled with new activities to be able to survive the passage of time. Locally many of the old prisons still hold a special position in people's memory, but their history will gradually fade away as time passes. A closer look 
at the messages the studied prisons bring forward reveals that although the social history and painful memories the prisons are steeped in are not consciously under-communicated, they play a minor role. A few of the prisons described in the article have underlined some of the most symbolic elements from prison architecture. They use the architecture as a form of "set pieces" for new performances; for example, to give an exciting frame for a running restaurant or hotel businesses (Stord, Skedsmo). Several other buildings have been reused as cultural institutions. Even if they are not necessarily stressing the building's original function in any considerable degree, the buildings have succeeded in keeping their original architectural form intact (Hønefoss, Stavanger, Halden), and by naming new functions or activities in accordance with the building's former use as a penal institution, parts of the history are kept alive (Skedsmo, Hønefoss). The stark social reality of imprisonment is more easily digestible when wrapped up and disguised. The description from Bergen, however, illustrates how powerful the use of the silent stories behind the prison walls can be when used as a medium in performance art, thereby filling emotional as well as educational purposes. It demonstrates that when used as a new resource in urban development, prisons represent excellent ground for creative initiatives.

\section{Conclusion}

Old buildings need to be handled with care, and the art of finding new functions is a challenge in itself. There is not one definite answer to the question indicated in the title of the paper: Whether the construction of prisons as heritage values is dominated by processes of concealment, spectacularisation, or recognised value assessments in heritage management. We can conclude, however, that even though we do not find many obvious examples of spectacularisation and commercialisation, the examples where the silent and dissonant individual prison histories are communicated are even fewer. The inherent language of power in prison architecture has by way of conservation policy been neutralised to mainly being a question of the buildings' ability to represent various stages in the history of the nation's legal system.

\section{Acknowledgements}

This paper has presented preliminary results from a case study recently started as part of a larger strategic research project, "Cultural heritage: Negotiations, politics and practice," initiated by the Norwegian Institute for Cultural Heritage Research and funded by The Norwegian Research Council.

\section{References}

[1] Staiger, U. and Steiner, H. 2009. Introduction, in: Staiger, U., Steiner, H. and Webber, A. (eds.) Memory Culture and the Contemporary City. Building Sites. New York: Palgrave Macmillan. 
[2] Markus, T.A. 1993. Buildings and Power. Freedom and Control in the Origin of Modern Building Types. London: Routledge.

[3] Tunbridge, J.E. and Ashworth, G.J. 1996. Dissonant Heritage: The Management of the Past as a Resource in Conflict. Chichester: Wiley.

[4] Logan, W. and Reeves, K. (eds.) 2009. Places of Pain and Shame: Dealing with "Difficult Heritage." London: Routledge.

[5] Al-Hosany, N. and Elkadi, H. 2001. Sustainability approaches for incarceration architecture; in Renewable and Sustainable Energy Reviews 6, 457-470.

[6] Edginton, B. 1997. Moral architecture: The influence of the York Retreat on asylum design, in Health and Place, Vol. 3, No. 2, pp. 91-99.

[7] Rosenthal, M. 2008. London versus Sydney, 1815-1823: The politics of colonial architecture, in Journal of Historical Geography 34, 191-219.

[8] Stone, P. and Sharpley, R. 2008. Consuming dark tourism: A thanatological perspective. Annales of Tourism Research, Vol. 35, No. 2, pp. 574-595.

[9] Strange, C. and Kempa, M. 2003. Shades of dark tourism. Alcatraz and Robben Island. Annales of Tourism Research, Vol. 30, No. 2, pp. 386-405.

[10] Tomlinson, H. 1984. Design and reform: The "separate system" in the nineteenth-century English prison; in A.D. King, Buildings and Society. Essays in the Social Development of the Built Environment. London: Routledge and Kegan Paul.

[11] Smith, L. 2006. Uses of Heritage. Abingdon and New York: Routledge.

[12] Marling, G. and Zerlang, M. (eds.) 2007. Fun City. Copenhagen: Arkitektens forlag.

[13] Rantisi, N. and Leslie, D. 2006. Branding the design metropole: The case of Montrèal, Canada. I: Area 38, 4, 364-376.

[14] Graham, B. Ashworth, G.J. and Tunbridge, J.E. 2000. A Geography of Heritage. Power, Culture and Economy. London: Arnold.

[15] Schirmer, H. E. and von Hanno, W. 1859. Planer over fengselsbygninger. Til det Kgl. Norske Justitis-Departement. Beskrivelse af Fængselsbygningerne. Beregninger over Omkostningerne ved Opførelsen af de på vedlagte Tegninger fremstillede Fængselsbygninger, Chra. 1859 (ill.)

[16] Hamran, R. 1962. Heinrich Ernst Schirmer og hans plass i norsk arkitekturhistorie. I: Fortidsminneforeningens årbok, 117 årgang, pp. 4384.

[17] Kjus, A. 2010. Justissektorens varelser. Landsverneplan for justissektoren: Historiedel. 4. mars 2010. http://www.regjeringen.no/upload/JD/Vedlegg/ Hoeringer/Justissektorens_vaerelser.pdf (accessed 1.12.2011)

[18] Nyborg, C. 2010. Eidsberg fengsel; i: Wiwar. Utg. Østfold historielag. S.13-22.

[19] Schaanning, E. 2007. Menneskelaboratoriet: Botsfengselets Historie. Oslo: Scandinavian Academic Press.

[20] Green Paper; Justis- og politidepartementet, Statsbygg og Forsvarsbygg 2010. Landsverneplan for justissektoren. Høringsutkast 
(Green Paper). http://www.riksantikvaren.no/Norsk/Prosjekter/ Landsverneplaner/ (accessed 1.12.2011).

[21] Wegner, R.B. 2009. Halden gamle fengsel; i: Wiwar, nr.2, 2009. utg. Østfold historielag. S.12-19.

[22] Fodstad, G. 2007. Kulturhistoriske eiendommer i justissektoren. Fortidsvern årg. 32, nr.3, s.8-10.

[23] Justis- og politidepartementets Stortingsmelding nr.37, 2007-2008. Straff som virker - mindre kriminalitet - tryggere samfunn (kriminalomsorgsmeldingen). Oslo.

[24] http://www.histos.no/bergen/vis.php?id=29\&kat=2 (accessed 16.1.2012).

[25] Bergen International Festival. 2011. Be Captivated! Bergen kretsfengsel 27.-28.mai og 3.-4. juni kl.21.00. Bergen: Skanner Grafisk.

[26] Drange, S. 2001. Hus og historie i Hønefoss. Hønefoss: Eikli Grafisk. 